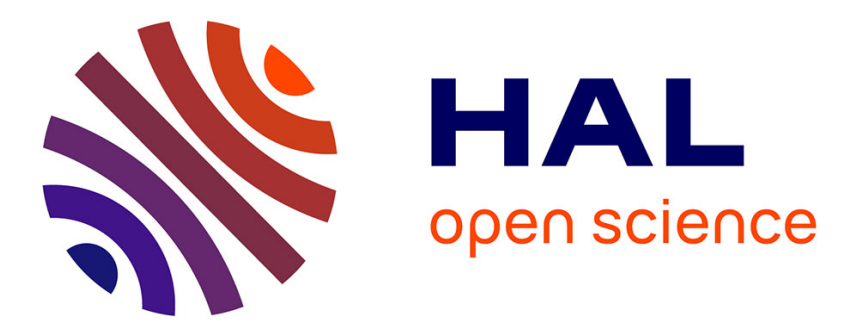

\title{
Occurrence, diversity and pattern of damage of Oplostomus species (Coleoptera: Scarabaeidae), honey bee pests in Kenya
}

\author{
Ayuka Fombong, Fiona Mumoki, Elliud Muli, Daniel Masiga, Richard \\ Arbogast, Peter Teal, Baldwyn Torto
}

\section{To cite this version:}

Ayuka Fombong, Fiona Mumoki, Elliud Muli, Daniel Masiga, Richard Arbogast, et al.. Occurrence, diversity and pattern of damage of Oplostomus species (Coleoptera: Scarabaeidae), honey bee pests in Kenya. Apidologie, 2012, 44 (1), pp.11-20. 10.1007/s13592-012-0149-6 . hal-01201267

\section{HAL Id: hal-01201267 \\ https://hal.science/hal-01201267}

Submitted on 17 Sep 2015

HAL is a multi-disciplinary open access archive for the deposit and dissemination of scientific research documents, whether they are published or not. The documents may come from teaching and research institutions in France or abroad, or from public or private research centers.
L'archive ouverte pluridisciplinaire HAL, est destinée au dépôt et à la diffusion de documents scientifiques de niveau recherche, publiés ou non, émanant des établissements d'enseignement et de recherche français ou étrangers, des laboratoires publics ou privés. 


\title{
Occurrence, diversity and pattern of damage of Oplostomus species (Coleoptera: Scarabaeidae), honey bee pests in Kenya
}

\author{
Ayuka T. Fombong ${ }^{1,2}$, Fiona N. Mumoki ${ }^{1}$, Elliud Muli ${ }^{1,4}$, Daniel K. Masiga ${ }^{1}$, \\ Richard T. Arbogast ${ }^{3}$, Peter E. A. Teal ${ }^{3}$, Baldwyn Torto ${ }^{1}$ \\ ${ }^{1}$ International Centre of Insect Physiology and Ecology (ICIPE), P.O. Box 30772-00100, Nairobi, Kenya \\ ${ }^{2}$ School of Biological Sciences, University of Nairobi, Chiromo Campus, P. O. Box 30197-00100, Nairobi, Kenya \\ ${ }^{3}$ USDA/ARS-CMAVE, 1600/1700 SW 23rd Dr., Gainesville, FL 32608, USA \\ ${ }^{4}$ Department of Biological Sciences, South Eastern University College, P. O. Box 170-90200, Kitui, Kenya
}

Received 23 March 2012 - Revised 8 May 2012 - Accepted 31 May 2012

\begin{abstract}
Several arthropod pests including the hive beetles Aethina tumida and Oplostomus haroldi and the ectoparasite Varroa destructor have recently been identified as associated with honey bee colonies in Kenya. Here, we report the first documentation of Oplostomus fuligineus in Kenya, a related scarab of $O$. haroldi, and distribution, diversity and pattern of damage of the two scarab species on honey bee colonies. Sequence analyses of mitochondrial cytochrome oxidase I gene revealed that there was sufficient sequence divergence to separate both Oplostomus beetles. The same molecular marker separated $O$. haroldi according to place of origin in Kenya. We further show from analysis of feeding behavioural patterns that the two scarab species damaged honey bee combs similarly causing the most damage on brood through feeding; $O$. haroldi (80\%), with $O$. fuligineus (100\%). We discuss our results in relation to the threats these scarabs may pose to bee health in Kenya.
\end{abstract}

honey bees / Oplostomus haroldi / Oplostomus fuligineus / scarab / cytochrome oxidase I gene

\section{INTRODUCTION}

Globally, beekeeping is an important economic activity with enormous direct and indirect benefits to both beekeepers and the environment. The realisation of the immense potential of the honey bee has led to a growing

Electronic supplementary material The online version of this article (doi:10.1007/s13592-012-0149-6) contains supplementary material, which is available to authorized users.

Corresponding author: B. Torto, btorto@icipe.org

Manuscript editor: Stan Schneider interest to comprehend its biology as evidenced from the vast amount of scholastic and nonscholastic literature on this insect. Studies and investigations spurred by this interest have led to breakthroughs and inventions which have shaped the history of beekeeping and bee research. Notably is the invention of the Langstroth box hive (Crane 1999; Graham 2004), currently regarded as the best hive type due to its worldwide adoption and usage by most beekeepers.

Thirty years ago, the Langstroth hive was introduced into Kenya and since then beekeepers have shown a growing preference for it over traditional ones (Raina 2006). In a recent 
survey of honey bee colonies maintained in Langstroth hives in Kenya, arthropod pests including the hive beetles Aethina tumida (Coleoptera: Nitidulidae) and Oplostomus haroldi (Coleoptera: Scarabaeidae), and the ectoparasite Varroa destructor implicated in colony losses in Europe and the USA were found (Frazier et al. 2011; Torto et al. 2010). Of the two coleopterans, A. tumida occurred predominantly on the bottom board of the Langstroth hive, while $O$. harold $i$ was a honey bee comb ivader (Torto et al. 2010). This finding suggests that $O$. haroldi is more likely to damage the honey bee colony than $A$. tumida. Although the nature of damage caused by $A$. tumida has previously been documented (Lundie 1940), similar information was lacking for $O$. haroldi. To close this gap, we carried out a detailed survey of honey bee colonies for scarab pests countrywide in Kenya and herein, report their (1) detailed occurrence and distribution, (2) identification based on their 658 base pair mitochondrial DNA barcode region (Hebert et al. 2003), and (3) patterns of damage based on recordings from an observation hive. Knowledge of the occurrence and distribution of these beetles could help develop beekeeping policies to prevent their spread into new areas in Kenya and their cost-effective management.

\section{MATERIALS AND METHODS}

\subsection{Survey sites and collection of specimens}

Twenty one beekeeping sites in 10 districts in five of the eight provinces (namely North-Eastern, Eastern, Central, Western and Coast provinces) in Kenya were surveyed for the presence of beetles in honey bee colonies during the major and minor wet seasons at various sites (Table $\mathrm{S} 1$ ). These sites were chosen to provide a representation of the major agro-ecological zones (humid, humid to sub-humid, semi-arid and arid zones) in Kenya (Reynolds 2004). Only honey bee colonies kept in Langstroth box hives were inspected for beetle infestation as this permitted comparison of beetle infestation levels across locations.
At all the sites, only colonies of honey bees without combs constructed across frames were chosen at random for inspection within each apiary. Depending on the number of bee colonies available at each apiary, $60-100 \%$ of the hives were randomly selected for inspection. Scarab beetles found at the top board, frames, inside walls of the hive box and its bottom board were handpicked and counted as described by Torto et al. (2010). All scarab beetles collected from the hives during the survey were tentatively identified to subfamily level using the external morphology of their mouth parts, head, legs and abdomen (Bland and Jaques 1978), maintained on moist sterile cotton wool in rectangular plastic bowls with perforated lids and brought back to the International Centre of Insect Physiology and Ecology (ICIPE) laboratory. The insects were then kept on substrate composed of sterilised cow dung and soil (mixed in the ratio 1:1 v/v) (Torto et al. 2010). Besides $O$. haroldi, another scarab, O. fuligineus (identified by M. Mutua, National Museums of Kenya, Nairobi, Kenya and confirmed by M. Barclay, Natural History Museum, London, UK), was also recovered from honey bee colonies. The different sexes of both Oplostomus species were distinguished using the morphology of their abdominal sterna, as described by Torto et al. (2010) for $O$. haroldi.

\subsection{Genetic diversity of Oplostomus specimens}

\subsubsection{Sample preparation}

Five male insects of each Oplostomus species and Pachnoda gedyei (a scarab which occurs in Kenya served as an outgroup species) were killed by freezing at $-20^{\circ} \mathrm{C}$ for $30 \mathrm{~min}$. All samples were stored in $85 \%$ ethanol at $4{ }^{\circ} \mathrm{C}$ prior to DNA extraction and analysis at ICIPE.

Similarly, a subset $(n=5)$ of each Oplostomus species (of mixed sexes) collected from various beekeeping sites were killed by freezing at $-20^{\circ} \mathrm{C}$ for $30 \mathrm{~min}$. The dead insects were later thawed and the left middle leg pulled off and stored in $85 \%$ ethanol at $4^{\circ} \mathrm{C}$ prior to shipment. The stored leg samples were then sent to the BOLD (Barcode of Life Data systems) laboratory hosted at the University of Guelph, Canada for DNA barcoding. 


\subsubsection{DNA extraction}

DNA was then extracted from the legs, using the CTAB DNA extraction protocol (Powell et al. 2006). Ten millilitres of isolation buffer $(2 \times$ CTAB composed of $100 \mathrm{mM}$ Tris- $\mathrm{HCl}$ at $\mathrm{pH} 8.0,1.4 \mathrm{mM} \mathrm{NaCl}$, $20 \mathrm{mM}$ EDTA and $2 \%$ cetyltrimethyl ammonium bromide-CTAB) containing $80 \mu \mathrm{L}$ of betamercaptoethanol in $50-\mathrm{mL}$ falcon tubes was preheated in $65^{\circ} \mathrm{C}$ water bath for $15 \mathrm{~min}$. Insect tissue from each beetle was homogenised in $150 \mu \mathrm{L}$ of the isolation buffer. Afterwards, $150 \mu \mathrm{L}$ of SEVAG buffer (comprising chloroform and isoamyalcohol in the ratio 24:1, respectively) was added into the homogenate and mixed gently. The homogenate was centrifuged at $150 \mathrm{rpm}$ for $60 \mathrm{~min}$ and later at 4,000 rpm for $20 \mathrm{~min}$. The supernatant of the homogenate $(\sim 500 \mu \mathrm{L})$ was then transferred into a fresh tube and the sediments discarded. Approximately $300 \mu \mathrm{L}$ of ice-cold isopropanol was added into the supernatant and the solution mixed gently and incubated at $-20^{\circ} \mathrm{C}$ overnight. The solution was then centrifuged at $3,000 \mathrm{rpm}$ for $5 \mathrm{~min}$ to precipitate the extracted DNA. The resulting supernatant was decanted carefully to avoid loss of DNA material. The precipitated DNA was washed twice with $70 \%$ ethanol, each time centrifuging at 3,000 rpm for $5 \mathrm{~min}$ and pouringoff the liquid phase. The precipitate was air dried by placing the tubes on their side for approximately $30 \mathrm{~min}$ and later resuspended in $40 \mu \mathrm{L}$ of Tris EDTA (composed of $10 \mathrm{mM}$ Tris- $\mathrm{HCl}$ at $\mathrm{pH}$ 8.0 and $0.25 \mathrm{mM}$ EDTA).

\subsubsection{PCR and DNA sequencing}

A 680-bp region of the $m t C O I$ gene was amplified by PCR using the primers LCO-1490 (5' GGTCAA CAAATCATAAAGATATTGG $3^{\prime}$ ) forward and HCO2198 (5' TAAACTTCAGGGTGACCAAAAAATCA $3^{\prime}$ ) reverse, previously described by Folmer et al. (1994) and known to amplify the $m t C O I$ gene in a wide range of invertebrate taxa. Amplification was carried out in $20-\mu \mathrm{L}$ reaction volumes containing 5 U GenScript Taq DNA polymerase, $1.25 \mathrm{mM}$ $\mathrm{MgCl}, 0.5 \mathrm{mM}$ dNTPs, $2 \mu \mathrm{M}$ of each primer, $1 \times$ GenScript buffer and $\sim 10 \mathrm{ng}$ of genomic DNA template. The PCR thermocycling was carried out under the following conditions: $2 \mathrm{~min}$ at $94^{\circ} \mathrm{C} ; 35$ cycles of $1 \mathrm{~min}$ at $94^{\circ} \mathrm{C}, 1 \mathrm{~min}$ at $46^{\circ} \mathrm{C}$ and $2 \mathrm{~min}$ at $72^{\circ} \mathrm{C} ; 10$ min at $72^{\circ} \mathrm{C}$; held at $10^{\circ} \mathrm{C}$. The PCR product was separated on a $1.2 \%$ agarose gel with ethidium bromide incorporated. The PCR product of $\sim 680 \mathrm{bp}$ (close to the target size) was excised from the gel and purified using GenScript QuickClean 5M Gel Extraction Kit (Piscataway, NJ, USA) following the manufacturer's instructions. The purified product was bi-directionally sequenced using the PCR primers on an ABI chain termination sequencing technology at a commercial facility (Macrogen Inc., Korea).

\subsection{Damage pattern of scarab beetles}

The aim of this experiment was to characterise the pattern of damage caused by Oplostomus species on honey bee combs. Honey bee combs constructed on standard hive frames $(48.3 \times 24.8 \mathrm{~cm})$ which contained bee brood (larvae and pupae), pollen and honey but which were void of adult bees were used. Adult bees attacked beetles and removed any brood fed upon by beetles making it difficult to qualify and quantify beetle damage in bee presence, thus necessitating their exclusion from this experiment. They were collected from honey bee colonies managed in Langstroth hives at the ICIPE apiary and brought to the laboratory. Photographs of both sides of each comb were taken before exposure to the beetles kept in an observation hive (k GS4005 model; Dadant, Hamilton, IL, USA). Adults of both Oplostomus species were introduced into the observation hive and kept in the dark for $24 \mathrm{~h}$ at $30 \pm 1{ }^{\circ} \mathrm{C}$ and relative humidity of $60 \pm 5 \%$ to mimic conditions inside a beehive. For $O$. haroldi, three treatments consisting of 20 males only (treatment 1), 20 females only (treatment 2) and a mixture of 10 males and 10 females (treatment 3) were released separately into the observation hive and the damage caused evaluated. Each treatment was replicated four times. Similarly, two treatments comprising six males and six females only were tested for $O$. fuligineus and replicated thrice. Treatment sizes were chosen based on results reported by Torto et al. (2010) for $O$. haroldi and from the first section of this study for $O$. fuligineus (which indicated peak infestation numbers 20 and six beetles per honey bee frame for $O$. haroldi and $O$. fuligineus, respectively). After $24 \mathrm{~h}$, the observation hives were opened, the beetles removed and the frames photographed. The number of brood, pollen and honey cells damaged by the beetles were 
counted, recorded and expressed as a percentage of the total number of cells on the frame. Damaged cells were identified as those showing partial or complete destruction which disrupted and or adversely affected their content. The total number of cells on each honey bee frame was estimated using a $10 \times 10 \mathrm{~cm}$ quadrat made of steel wire. The quadrat was gently pushed onto one side of the bee frame and the number of cells within it counted. This procedure was replicated three times using both sides of the frames while avoiding areas damaged by the beetle and the three replicates used to compute the average cell number per $10 \mathrm{~cm}^{2}$ of the comb. The total cell number on each bee frame was computed using the formula below and assuming perfect symmetry in comb structure:

$N=2[n \times q]$,

where $N=$ total cell number on frame, $n=$ average number of cells $/ 10 \mathrm{~cm}^{2}$ and $q=$ number quadrats that completely fit one side of the bee comb.

\subsection{Data analysis}

\subsubsection{Distribution of Oplostomus species}

Logistic regression and pairwise orthogonal comparisons were used to compare beetle counts across apiaries and sites where each beetle species was recovered. Comparisons were carried out only for sites surveyed within the same month of the year. All analyses were done at $\alpha$ level of 0.05 using the statistical software $\mathrm{R}$ version 2.1.3.0 (R Development Core Team 2011).

\subsubsection{MtCOI sequence variations and genetic diversity}

DNA sequences were edited manually using BIOEDIT (Hall 1999) to give consensus sequences. The primer sequences were removed from the consensus sequences resulting in a 658-bp fragment. The sequences were checked for open reading frames using the Transeq program hosted by the European Molecular Biology Open Software Suite (EMBOSS) (http://emboss.open-bio.org). The 658-bp sequences were then submitted to BOLD

Multiple sequence alignment was done using ClustalX version 1.81. Phylogenetic relationships between the samples were inferred from trees constructed using the neighbour-joining $(\mathrm{NJ})$ tree method in MEGA 4.0 (Tamura et al. 2007), with 1,000 bootstrap replicates. Intra- and interspecific sequence divergence distances based on Kimura two-parameter (Kimura 1980) between individual species and groups of populations were also determined.

\subsubsection{Damage pattern of Oplostomus species}

The proportions of the honey bee frames damaged among treatments for each species were compared using a Kruskal-Wallis ANOVA on ranks and MannWhitney test. The proportions of brood, honey and pollen cells damaged within each treatment were compared using Kruskal-Wallis ANOVA and MannWhitney $U$ test on ranks. Non-parametric tests were used to analyse the data as their variances were unequal. All analysis were done at an $\alpha$ level of 0.05 using the statistical software $\mathrm{R}$ version 2.1.3.0 ( $\mathrm{R}$ Development Core Team 2011).

\section{RESULTS}

\subsection{Distribution of Oplostomus species in Kenya}

Out of a total of 108 honey bee colonies inspected from 35 apiaries in 22 locations, 14.8\% colonies in six locations showed infestation by both Oplostomus species (Figure 1). The occurrence of $O$. fuligineus (Figure $2 \mathrm{~b}$ ) was limited to the eastern province while $O$. haroldi (Figure 2a) was found in the coast and eastern provinces.

A total of 96 adult $O$. haroldi were recovered from Kitui (11), Mtwapa (2) and Muhaka (83) while 26 O. fuligineus adults were recovered from Kinna (16), Isiolo Central (9) and Il Parua (1). Infestation levels of $O$. haroldi were significantly different between Kitui and Mtwapa $\left(\chi^{2}=7.21, P=0.007\right)$. Similarly, there were significant differences in counts of $O$. fuligineus across sites where it occurred $\left(\chi^{2}=3.39, P=0.009\right)$. Nevertheless, pairwise orthogonal comparisons showed that the occurrence of $O$. fuligineus did not vary 


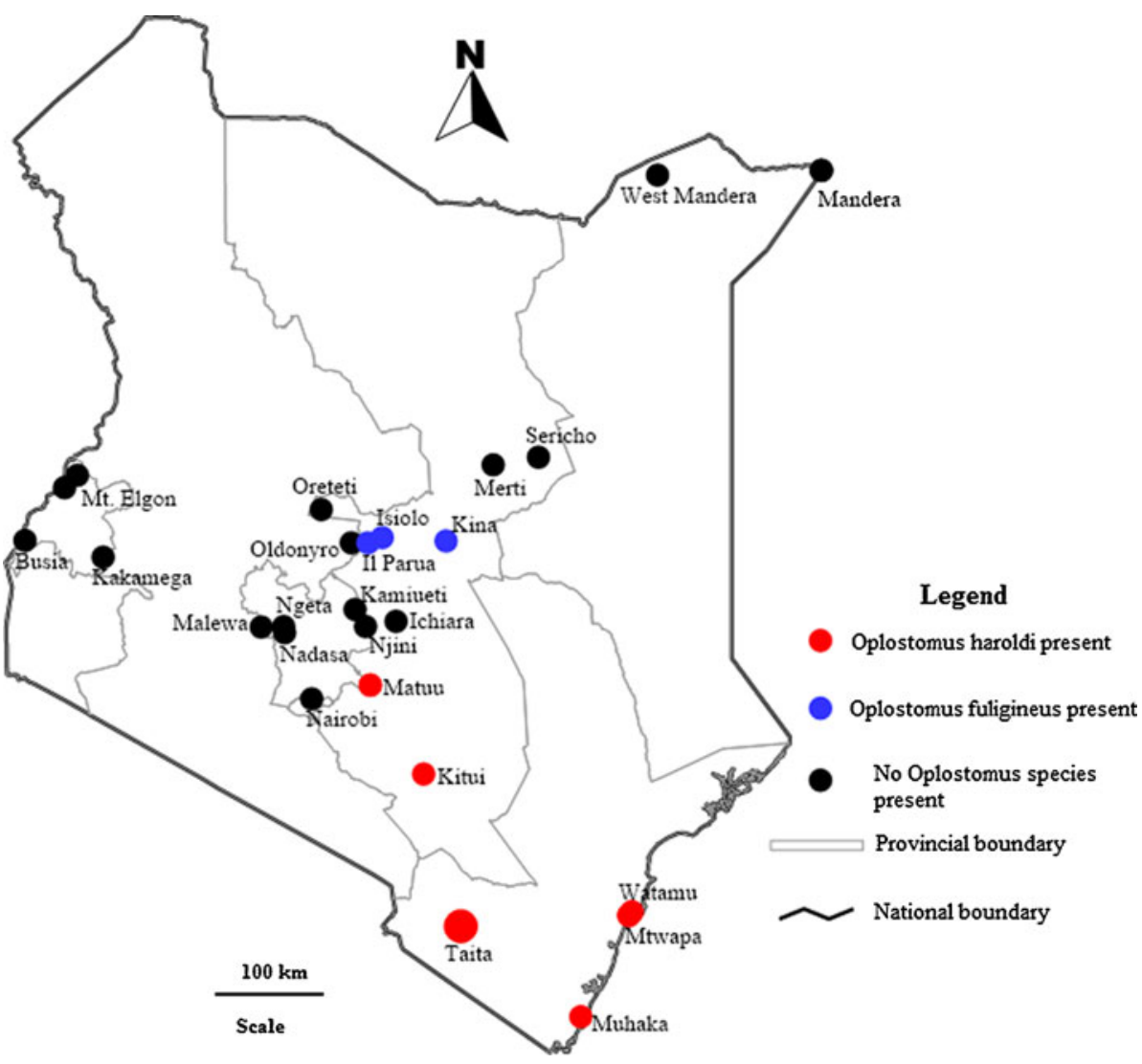

Figure 1. Map of Kenya showing all locations surveyed (represented by closed circles) for hive beetles between June 2009 and May 2011 (updated from Torto et al. 2010). Blue dots represent presence of $O$. fuligineus, red dots indicate presence of $O$. haroldi and black dots represent surveyed areas where no Oplostomus species were recovered from honey bee colonies.

significantly across and within the three locations $(P>0.05)$. The majority of both beetle species were observed on the frames inside the hives.

\section{2. $M t C O I$ sequence variation and genetic diversity}

A total of 28 sequences were used for analyses. All sequences were highly AT biased with an average $\mathrm{A}+\mathrm{T}$ content of $66 \%$. The average interspecific K2P distance was lowest between $O$. haroldi and $P$. gedyei (17.4\%), followed by that between $O$. harold $i$ and $O$. fuligineus (17.7\%) and highest between $O$. fuligineus. and P. gedyei (20.9\%) (Figure 3a). Intraspecific distances averaged $1.6 \%$ across all three scarabs and varied from $0.1 \%$ in $O$. fuligineus, through $1.6 \%$ in $P$. gedyei to $3.0 \%$ in $O$. haroldi. The evolutionary relationships between both Oplostomus beetles and the outgroup $P$. gedyei revealed two clusters, one containing both Oplostomus species and the other $P$. gedyei (Figure 3a). All mitochondrial sequences $(n=14)$ have been deposited in GenBank under accession numbers JQ658361JQ658374.

A similar neighbour-joining (NJ) cluster analysis carried out for $O$. haroldi samples from four different locations showed that they clus- 

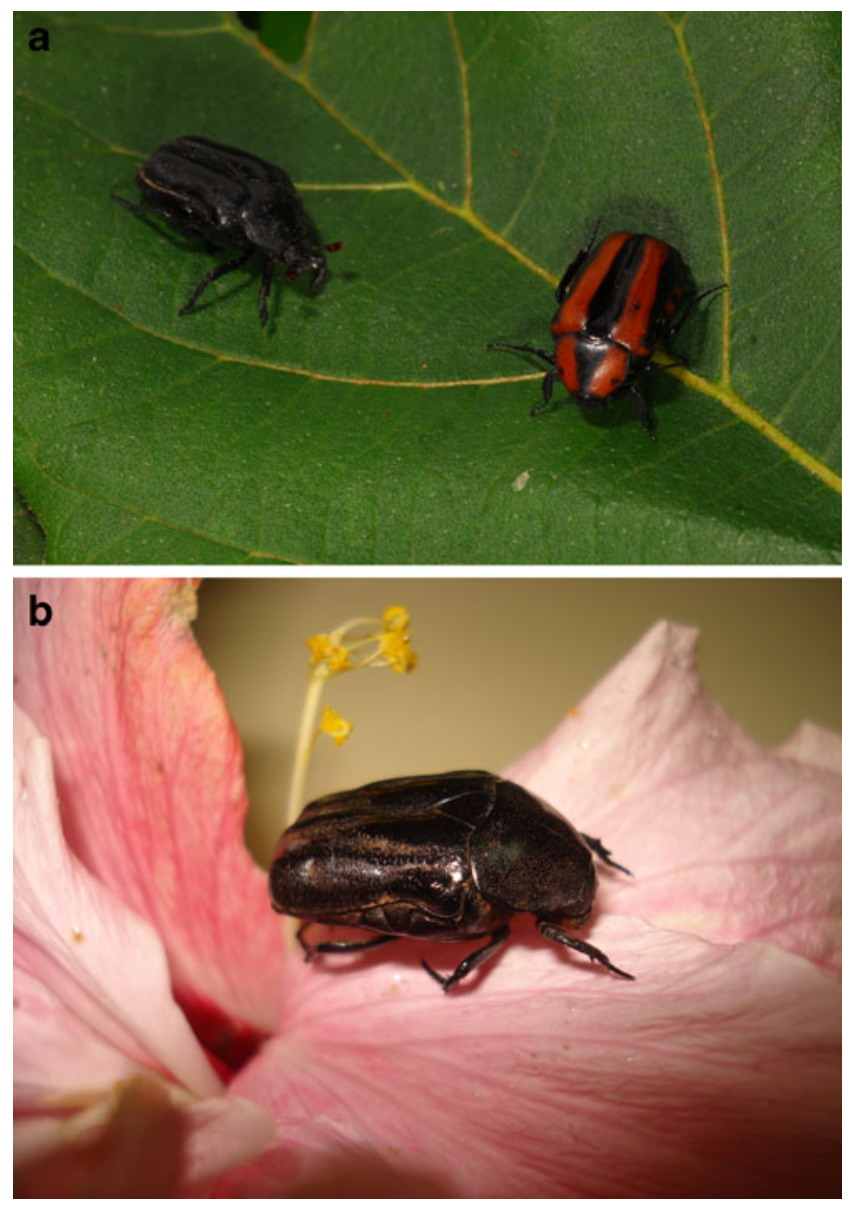

Figure 2. Adults of a Oplostomus haroldi and b Oplostomus fuligineus recovered from honey bee colonies in Kenya.

tered into three groups according to their locations of origin except for the lone sample from Matuu which was part of the Taita group (Figure 3b). All mitochondrial sequences of $O$. haroldi beetles originating from the different locations have been deposited in the GenBank with accessions HQ962707-HQ962715 and HQ962718-HQ962721.

\subsection{Damage pattern of Oplostomus species}

$O$. haroldi fed on brood (both capped and uncapped), honey and pollen on the combs while $O$. fuligineus only fed on brood (Figure 4). Feeding resulted in a characteristic damage pattern consisting of either small (1-3 cells) and large ( $>5$ cells) clusters of damaged cells. The small cells were derived from feeding on a fourth or fifth instar larva or pupa across neighbouring cells, while large clusters resulted from either burrowing into a single cell containing second or third instar larva or capped pupa cell. Both species consumed more brood compared to honey and pollen (Table I) $\left(H_{2,9}=\right.$ 8.011, $P<0.001 ; U<0.0001, P=0.029$ for treatments 1 and 3 ), which reflected a nonsignificant pattern between the different treatments of each species $\left(H_{2,9}=0.382, P=0.826\right.$ and $U=4.0, P=1.0$ for $O$. haroldi and $O$. fuligineus, respectively). 


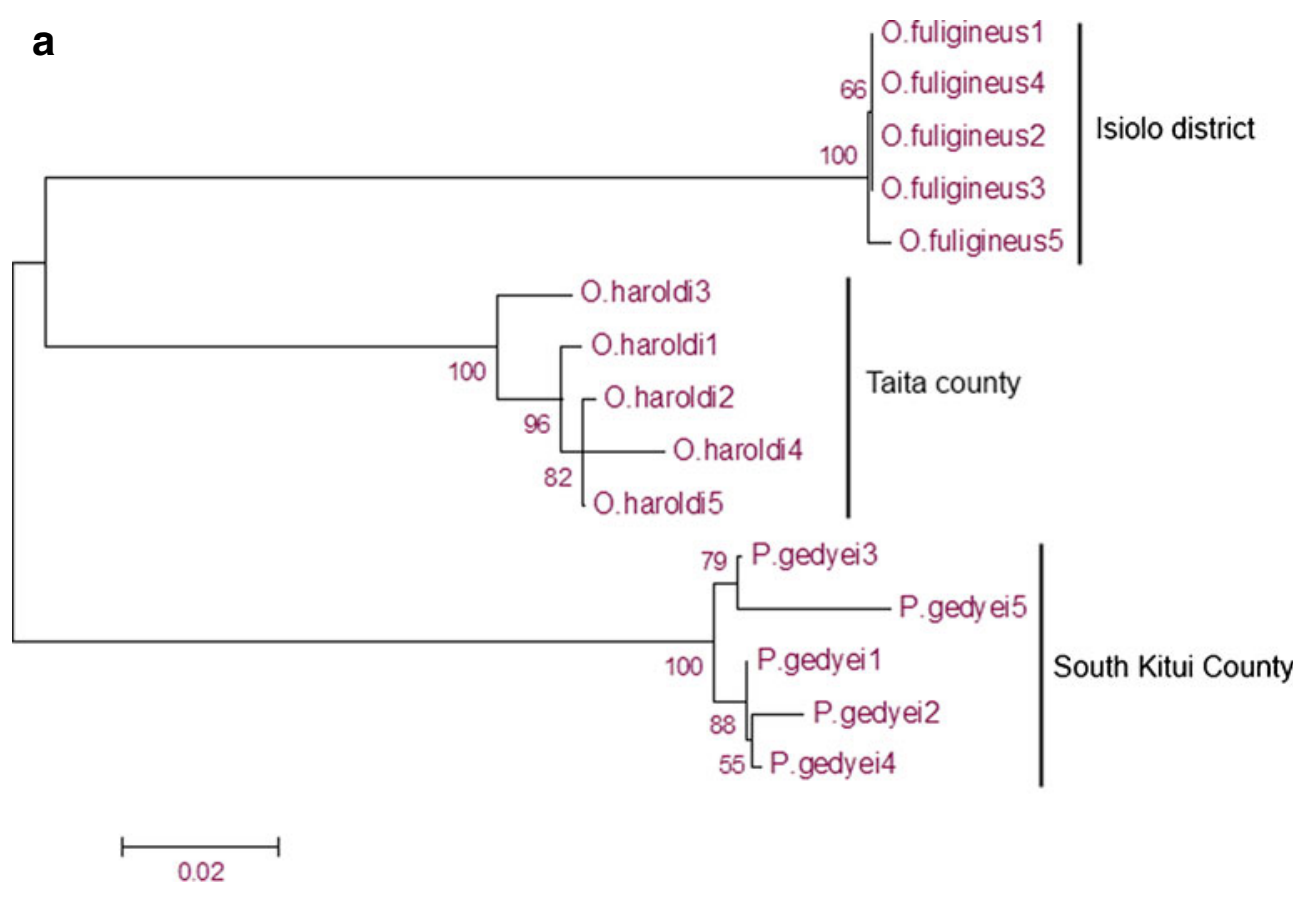

b

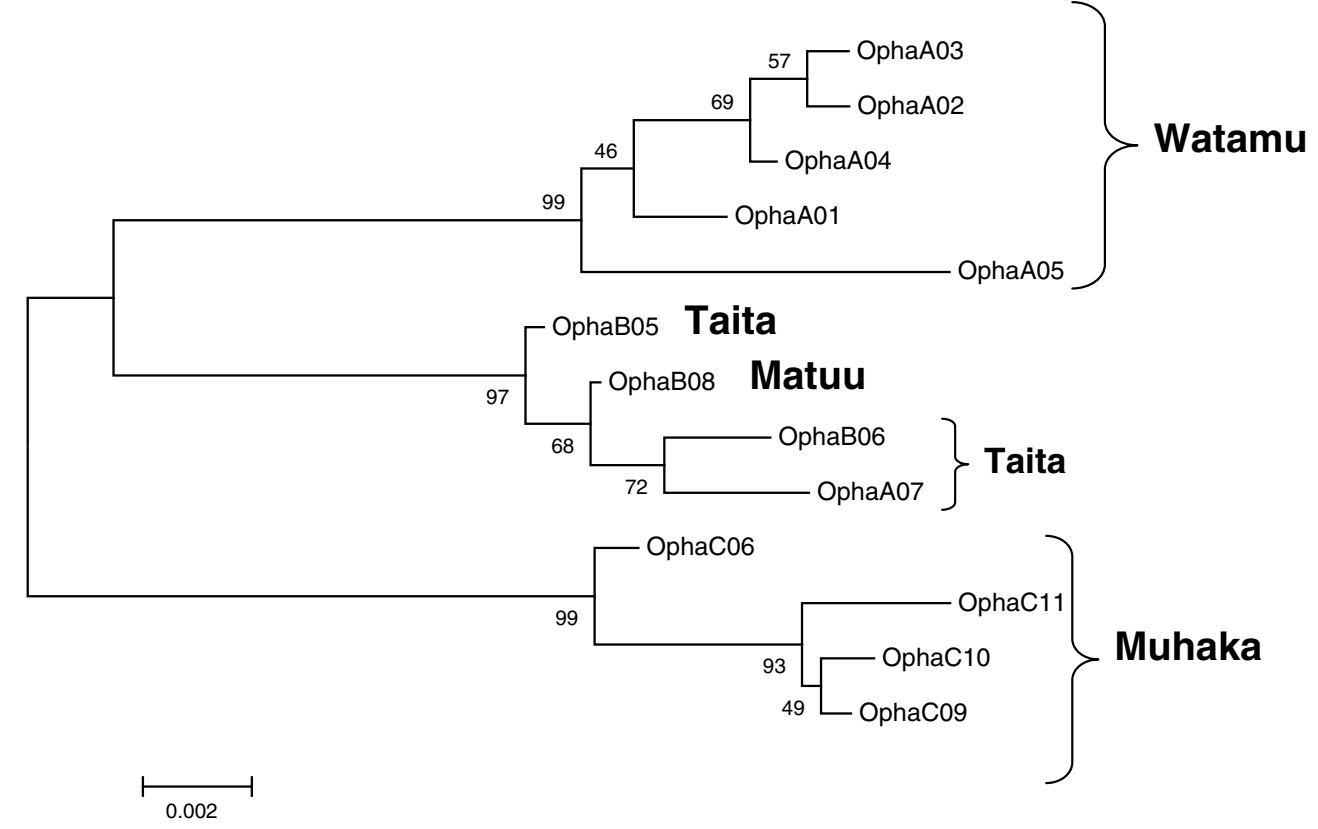

Figure 3. Summary of evolutionary relationship of a five samples of $O$. haroldi and $O$. fuligineus with Pachnoda gedyei as an outgroup and b 13 samples of $O$. haroldi from four different locations analysed using the neighbour-joining tree method. This tree was inferred from 1,000 bootstraps whose values are shown next to the branches. 

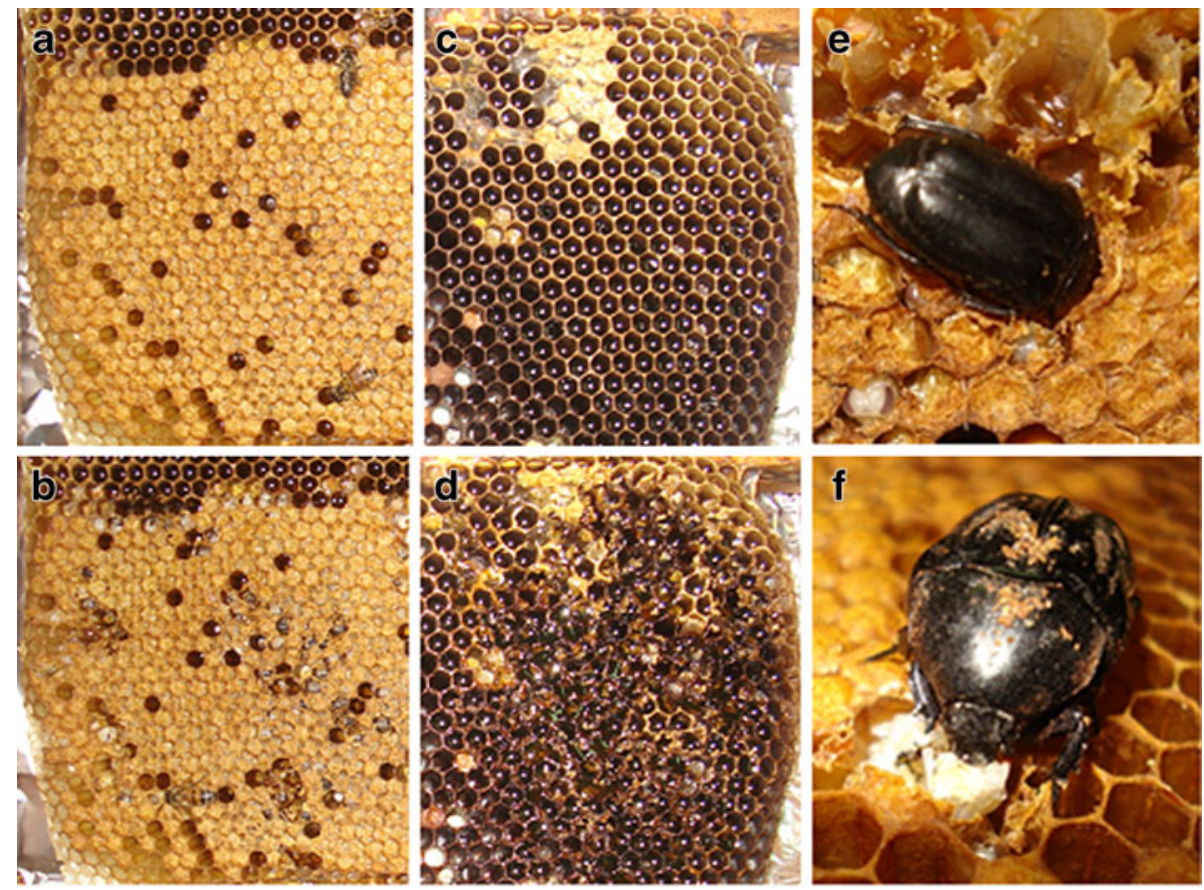

Figure 4. Pattern of damage for Oplostomus species. a Section of frame before damage, $\mathbf{b}$ frame section after damage showing uncapped cells, $\mathbf{c}$ section of frame before damage, $\mathbf{d}$ section of frame showing damage to uncapped honey cells, $\mathbf{e}$ beetle burrowed deep into comb while feeding on brood and $\mathbf{f}$ beetle feeding on brood on comb surface.

\section{DISCUSSION}

The present results show a clear occurrence pattern and diversity of large hive beetles in Kenya. Two large hive beetle species $O$. haroldi and $O$. fuligineus were found in Langstroth hives in specific non-overlapping areas; $O$. fuligineus occurred mainly in the semi-arid eastern area whereas $O$. haroldi occurred predominantly within the coastal and highland areas of Kenya, in agreement with previous findings (Torto et al. 2010). It is unclear why the two related scarabs appear not to overlap in their geographic range, but it is possible that geographical physical barriers (e.g. Mt. Kenya) could play a role to limit their spread into new areas in Kenya. The fact that migratory beekeeping for pollination of crops is not practiced in Kenya may also be a key contributing factor. On the other hand, the small hive beetle $A$. tumida was found at all the survey sites co- existing with these scarabs inside the hive. The difference in the geographic ranges of the scarabs and the nitidulid may be associated with their different oviposition and reproductive behaviours. While A. tumida can reproduce inside the honey bee colony, the scarabs require decomposing plant materials and herbivore faeces for oviposition and larval development as observed in the field for $O$. fuligineus by Donaldson (1989) and Johannesmeier (2001), and demonstrated under laboratory conditions for $O$. haroldi by Fombong et al. (2012).

The $m t C O I$ gene sequences generated from this study segregated $O$. haroldi from $O$. fuligineus and may serve as taxonomic barcodes for their identification. The $\mathrm{A}+\mathrm{T}$ content of these sequences were similar to those reported for other beetles (Raupach et al. 2010; Monaghan et al. 2005). Exploratory analyses of $m t C O I$ gene fragment obtained from $O$. haroldi collected at different locations revealed 
Table I. Quantification of damage on honey bee combs by both Oplostomus haroldi and O. fuligineus.

\begin{tabular}{llllll}
\hline \multirow{2}{*}{ Species } & Treatments & Damage on frame (\%) & \multicolumn{2}{l}{ Percentage of brood, honey and pollen } \\
\cline { 4 - 6 } & & & Brood & Honey & \multicolumn{2}{l}{ Pollen } \\
\hline Oplostomus haroldi & $1(\mathrm{M}$ and F) & $1.7 \pm 0.74$ & $87.4 \pm 9.38 \mathrm{a}$ & $7.6 \pm 7.63 \mathrm{~b}$ & $5.0 \pm 2.89 \mathrm{~b}$ \\
& $2(\mathrm{M})$ & $2.4 \pm 1.11$ & $54.9 \pm 19.5$ & $40.7 \pm 20.64$ & $4.4 \pm 3.53$ \\
& $3(\mathrm{~F})^{\mathrm{a}}$ & $1.7 \pm 1.01$ & $99.1 \pm 0.67 \mathrm{a}$ & 0 & $0.9 \pm 0.67 \mathrm{~b}$ \\
Oplostomus fuligineus & $1(\mathrm{M})$ & $0.6 \pm 0.15$ & 100 & 0 & 0 \\
& $2(\mathrm{~F})$ & $0.8 \pm 0.38$ & 100 & 0 & 0 \\
\hline
\end{tabular}

$M$ males only treatment, $F$ females only and $M \& F$ mixed sex

${ }^{\text {a }}$ Treatment row values followed by the same letter are not statistically significantly different at $P=0.05$

population-specific haplotypes (not shown). However, the clustering of one $O$. haroldi individual from Matuu with others from Taita suggests the necessity to use additional molecular markers to resolve population-related differences. Although mtCOI sequence analysis demonstrated its usefulness as a taxonomic tool to separate the two beetle species, a larger sample size from different locations may be required to gain more insight into the genetic variability of the scarab pests of honey bees in Kenya. Previous studies by Omondi et al. (2011) and Raupach et al. (2010) showed that $m t C O I$ gene sequences enabled discrimination of different species of beetles with a higher accuracy compared to other molecular markers such as ITS (internal subscribed spacers) and rDNA (ribosomal DNA). The barcodes generated from this study will improve the delineation of these beetles from one another.

Our data show that both species of beetles fed more on brood than on any other hive food source. The strong preference for brood may be due to an innate biological demand for nutrients essential for survival and reproduction of the beetles. These findings confirm those of a previous study by Donaldson (1989) which reported that $O$. fuligineus consumed mainly brood when in the field, but also fed on pollen and honey when maintained in the laboratory. Interestingly, this author noted that the beetle was only capable of reproduction when fed on brood, suggesting that olfactory or contact cues may be involved in their food selection. This suggestion warrants further study. Herein, we also provide the first quantitative estimates for $O$. haroldi and $O$. fuligineus damage to combs in the absence of bees. Besides their damage to hive resources, they also destroyed the comb structure. However, it would be interesting to investigate scarab damage in bee-occupied frames in order to obtain a clear assessment of their potential threat to bee production in the affected areas.

In summary, this study has provided the first evidence of the detection of $O$. fuligineus as a pest of honey bee colonies in Kenya. This study also advances current knowledge of potential threats to honey bee health in East Africa and lays a foundation for strategies for mitigation.

\section{ACKNOWLEDGEMENTS}

The authors are grateful to J. Kilonzo, N. Onyango, J. Nganga and E. Mokua for their assistance during the inspection of honey bee colonies; M. Mutua (National Museums of Kenya, Nairobi) and Dr M. Barclay (National History Museum, London) for identification of Oplostomus fuligineus. ATF was funded through a studentship provided by the German Academic Exchange Service (DAAD). The authors are also grateful to theBarcode of Life Data systems laboratory hosted at the University of Guelph for generating some beetle barcodes. Lastly, the authors acknowledge the United States Department of Agriculture's Agricultural Research Service (USDA-ARS) for funding this project (SCA-586615-7-119F). 
Présence, diversité et types de dégâts des espèces d'Oplostomus (Coleoptera: Scarabaeidae), ennemies des abeilles au Kenya

Abeille / Oplostomus haroldi / Oplostomus fuligineus / gène de la cytochrome oxydase I

Vorkommen, Diversität und Schadbilder verschiedener Oplostomus-Arten (Coleoptera:Scarabaeidae), Schädlinge der Honigbiene in Kenia

Honigbienen / Oplostomus haroldi / Oplostomus fuligineus / Scarabäidae / Cytochromoxidase I Gen

\section{REFERENCES}

Bland, R.G., Jaques, H.E. (1978) How to Know the Insects. Brown, Cincinnati

Crane, E. (1999) The World History of Beekeeping and Honey Hunting. Duckworth, London

Donaldson, J.M.I. (1989) Oplostomus fuligineus (Coleoptera Scarabaeidae): life cycle and biology under laboratory conditions, and its occurrence in bee hives. Coleopt. Bull. 43, 177-182

Folmer, O., Black, M., Hoeh, W., Lutz, R., Vrijenhoek, R. (1994) DNA primers for amplification of mitochondrial cytochrome $\mathrm{c}$ oxidase subunit I from diverse metazoan invertebrates. Mol. Mar. Biol. Biotechnol. 3, 294-299

Fombong, A.T., Haas, F., Ndegwa, P.N., Irungu, L.W. (2012) Life history of Oplostomus haroldi (Coleoptera: Scarabaeidae) and a description of its third instar larva. Int. J. Trop. Insect Sci.. doi:10.1017/ S1742758412000021

Frazier, M., Muli, E., Coklin, T., Schmel, D., Torto, B., Frazier, J., Tumlinson, J.H., Raina, S. (2011) A scientific note on Varroa destructor found in East Africa: threat or opportunity? Apidologie 41, 463-465

Graham, J.M. (2004) The Hive and the Honey Bee. Dadant, Hamilton

Hall, T.A. (1999) BioEdit: a user friendly biological sequence alignment editor and analysis program for Windows 95/98/NT. Nucleic Acid Symp. Ser. 4, 95-98

Hebert, P.D.N., Cywinske, A., Ball, S.L., DeWaard, J.R. (2003) Biological identifications through DNA barcodes. Proc. R. Soc. B. 270, 313-321

Johannesmeier, M.F. (2001) Beekeeping in South Africa. Plant Protection Research Institute, Pretoria
Kimura, M. (1980) A simple method for estimating evolutionary rates of base substitution through comparative studies of nucleotides sequences. J. Mol. Evol. 16, 111-120

Lundie, A.E. (1940) The small Hive Beetle Aethina tumida. Science bulletin 220, Department of Agriculture and Forestry, Government printer, Pretoria, South Africa.

Monaghan, M.T., Balke, M., Gregory, T.R., Vogler, A.P. (2005) DNA based species delineation in tropical beetles using mitochondrial and nuclear markers. Phil. Trans. R. Soc. B. 360, 1925-1933

Omondi, B.A., Van den Berg, J., Masiga, D., Schulthess, F. (2011) Phylogenetic structure of Teretruis nigrescens (Coleoptera: Histeridae) predator of the invasive harvest pest Prostephanus truncatus (Coleoptera: Bostrichidae). Bull. Entomol. Res. 101, 521-532

Powell, M., Van der Bank, M., Maurin, O., Savolainen, V. (2006) DNA Barcoding: A Practical Guide. Available online at http://acdb.co.za/uploads/File/ TreeBol/MOLECULAR\%20PROTOCOLS.web.pdf.

R Development Core Team (2011) R: A Language and Environment for Statistical Computing. R Foundation for Statistical Computing, Vienna, Austria. ISBN 3-900051-07-0, URL http://www.r-project.org/.

Raina, S.K. (2006) Role of the commercial insects program, p. 11. In: Proceedings of the International Workshop on Promotion of income Generation Activities in the NENA Region Based on Sericulture and Apiculture organised by IDB/IFAD, 9-10 July, Cairo, Egypt.

Raupach, M.J., Astrin, J.J., Hannig, K., Peters, M.K., Stoeckle, M.Y., Wägele, J.-W. (2010) Molecular species identification of Central European ground beetles (Coleoptera: Carabidae) using nuclear rDNA expansion segments and DNA barcodes. Front. Zool. 7. doi:10.1186/1742-9994-7-26

Reynolds, C. (2004) United States Department of Agriculture Foreign Agriculture Service (USDAFAS) Commodity Intelligence Report. http:// www.pecad.fas.usda.gov/highlights/2008/09/kenya/ KenyaAgro-ecologicalZones.htm.

Tamura, K., Nei, M., Kumar, S. (2007) MEGA4: Molecular Evolution Genetics Analysis (MEGA) software version 4.0. Mol. Biol. Evol. 24, 1596-1599

Torto, B., Fombong, A.T., Mutyambi, D.M., Muli, E., Arbogast, R.T., Teal, P.E.A. (2010) Aethina tumida (Coleoptera: Nitidulidae) and Oplostomus haroldi (Coleoptera: Scarabaeidae): occurrence in Kenya, distribution within honey bee colonies and responses to host odors. Ann. Entomol. Soc. Am. 103, 389-396 